\title{
The Rise and Fall of the Hua-Yi System in East Asia
}

\author{
Han Dongyu 韓東育 \\ Professor of History, Northeast Normal University, China \\ handy916@nenu.edu.cn
}

\begin{abstract}
The Hua-Yi 華夷 system that spread in East Asia in the form of tribute relationships during the Ming dynasty [1368-1644] began as a system based on China's perceived cultural superiority, but slowly evolved into a system centered on nationalism. Accordingly, the kinship networks embedded in the Hua-Yi system were also continually evolving, breaking down, and reforming in a cycle that repeated itself multiple times. Amid this process, ethnocentrism [zi minzu zhongxin zhuyi 自民族中心主義] and “interest centralism" [liyi zhongxin zhuyi 利益中心主義] played key roles in the formation and eventual dissolution of the Hua-Yi system.
\end{abstract}

\section{Keywords}

East Asia - international relations - Ming history - Qing history - tributary system

$\mathbf{1}$

The Hua-Yi 華夷 ${ }^{1}$ system was a system of geographic relationships centered on the dynasties in the Central Plains region of China, which persisted for more than 2,00o years in parts of East Asia and Southeast Asia. Through a series of both tangible and intangible rules, the system successfully and effectively wove China's sphere of cultural influence into a network of organic political, economic, and cultural relations. It was also responsible for the creation of a fledgling system of international relations during the Spring and Autumn period [770-476 BCE] and the creation of ancient China's international law

1 Hua 華 refers to the Chinese people, and $y i$ 夷 is a derogatory term referring to the tribes living east of the Central Plains, considered the birthplace of Chinese civilization. 
system, both of which are recognized even by contemporary Western proponents of the international treaty system.

The term "East Asia" stems from the term "Far East" in Western languages and has an equivalent in Japanese, "Far East" or "absolute East." John King Fairbank [1907-1991] said:

East Asia has three meanings. Geographically, East Asia refers to the eastern part of Asia which is divided from the rest of the continent by high mountains and desert. Ethnographically, east Asia refers to the region of the ethnic Mongols [excluding Eskimos and American Indians]. Culturally, it refers to regions that were deeply influenced by the culture of ancient China. The last definition is the narrowest: outside of China, only Japan, Korea, and Vietnam fall into this category. ${ }^{2}$

What has received less attention is that as the Central Plains [Zhongyuan 中原] civilizations were developing their "international law," their system involved categorizing peoples according to their lifestyle, food, and drink customs. The ancient Chinese often classified peoples based on whether they lived indoors and ate cooked food, for example, as a tangible criterion to differentiate humans and animals. ${ }^{3}$ In practice, though, the tribes living on the borderlands of ancient China were recognized as human but had different lifestyles from the Chinese and so were classified as "other." This led to the formalization of the "four barbarians" [yi man rong di 夷蠻戎狄] classification-a wellknown term in China that combines derogatory labels for the non-Chinese tribes living north, east, south, and west of the Central Plains. Importantly, this classification became a persistent stereotype. As late as the Ming dynasty [1368-1644], the scholar Xie Zhaozhe 謝肇淛 [1567-1624] was recorded as saying, "Followers of the sages eat cooked food; in this way the Chinese are distinguished from the northern and eastern barbarians, and people are separated from beasts." 4

This demonstrates the sense of superiority that the agricultural societies of the Central Plains exhibited toward the nomadic societies living on their borderlands. Xingshan 腥膻 (literally translated as the smell of meat or fish,

2 John King Fairbank 費正清, Zhongguo: Chuantong yu bianqian 中國: 傳統與變遷 [China: Tradition and Transformation], trans. Zhang Pei 張沛 (Beijing: Shijie zhishi chubanshe, 2002), 4.

3 Han Fei 韓非, “Wu du 五蛽 [Five Kinds of Moths],” in Han Feizi jijie 韓非子集解 [The Collected Commentaries on Han Feizi], annot., Wang Xianshen 王先慎, Zhuzi jicheng 諸子 集成 [Collected Interpretations of Zhuzi] (Shanghai: Shanghai shudian, 1986), 5.339.

4 Xie Zhaozhe 謝肇淛, Wu za zu 五雜組, annot., Fu Cheng 傅成 (Shanghai: Shanghai guji chubanshe, 2012). 
though also a figurative expression meaning bad things or evil forces) became a characteristic of the border tribes in the eyes of the Central Plains peoples, implying that the non-Chinese civilizations needed the help and tutelage of the Chinese people to advance and develop. Furthermore, as a prerequisite for accepting this aid, the tribes had to acknowledge their inferiority and venerate the Central Plains culture as a center of civilization on which they were dependent and which they should attempt to imitate. As Chinese culture spread, then, the borderlands of the Central Plains dynasties not only became accustomed to living under the Hua-Yi and the tribute systems but also, in some cases, viewed Sinicization as a responsibility and even an advantage.

The Joseon 朝鮮 dynasty [1392-1910] philosopher and novelist Bak Ji-won 樸趾源 [1737-1805] said, “The East admires the Chinese and their nature." Until the mid-fifteenth century, the Vietnamese still positioned themselves as "barbarians," as shown in a letter of thanks to a Ming dynasty [1368-1644] emperor, which read, "The four seas are bestowed with China's goodwill. [China] manages the barbarians by not managing them too closely." Even though Japan and China were perpetually rivals, Prince Kaneyoshi 懷良親王 [1329-1383], the commander-in-chief of the Western Defense Area during the Kamakura 鐮倉 period [1185-1333], said of the Ming dynasty: "Only the Chinese have regard for their sovereigns; how is it that the barbarians have none?"7 This shows that he acknowledged his own people were "barbarians."

2

The Hua-Yi system, which differentiated between the "humble" [beixia 卑下] non-Chinese tribes and the "respected" [zungui 尊貴] and "legitimate" [zhengtong 正統] Chinese, relied historically on the practices of tribute and bestowing titles. These practices took place within the sphere of influence of the Central Plains dynasties and were based on a list of standards that included the strength of kinship relations, the perceived level of cultural development, the military strength, the economic might, and the moral achievements of China's neighbors. These standards constituted a network of relations based on "rights and obligations." Takeshi Hamashita 濱下武志 has shown that the

5 Bak Ji-won 樸趾源, Rehe riji 熱河日記 [The Diary in Rehe] (Shanghai: Shanghai shudian chubanshe, 1997), 213 .

6 Li Wenfeng 李文鳳, “Biao shu 表書," in Yue qiaoshu 越嶠書, Taiwan lishi yuyan yanjiusuo tushu guan 臺灣歷史語言研究所圖書館, manuscript edition, ce 5, 15.98.

7 Zhang Tingyu 張廷玉 et al., "Riben zhuan 日本傳 [Records of Japan]," in Mingshi 明史 [History of the Ming Dynasty] (Beijing: Zhonghua shuju, 200o), 322.5588. 
tribute system, which fell under the framework of the Hua-Yi system, had several basic characteristics. First, China provided a guarantee of international security. Second, the tribute system was built on the foundations of China's overwhelming economic advantages. Third, in order to enter into a tribute relationship with China, nations only had to fulfill the demands of the tribute system (i.e., presenting tribute to the emperor, bestowing titles); there were no other requirements. This implies that China also acted as an intermediary in promoting exchange between different cultures. ${ }^{8}$

However, over time, the tribute system was eroded by the loss of some of its original principles - among them, that China generally contributed more than it received in the tributary relationship. Beginning in the mid-Qing dynasty [1644-1911], tribute nations could no longer necessarily receive the benefits that they had come to expect from the tribute system, as the Chinese government began to rely more and more on the tribute system as a means of financial support. It increased the amount of tribute required but could not always give its tribute partners the commodities that they needed in equal value, so it began to pay them in paper money, instead. This inspired fierce criticism by the ethnic Chinese merchants living on the borderlands of the Qing empire who carried out the tribute trade. At the same time, as Asian trade networks expanded, private commercial forces that were initially tied to the tribute system eventually reduced their reliance on the system and even became powerful commercial forces in their own right. ${ }^{9}$

In practice, in modern times the Hua-Yi system was little more than a system of trading rituals and customs. Nations that had territorial relations or economic relations with China could enter into tributary relations with China very simply. If the "tribute nations" acknowledged the nominal rule of the Chinese dynasties and obeyed the other procedural requirements of the tribute system, they were considered legitimate. Because the tribute nations saw economic benefits as their primary motivation, they regarded the attendant rituals and status as "admission tickets." As long as the nations that formed the core of the tribute system had sufficient political and economic power to maintain their status, they naturally were reluctant to question the rules of the Hua-Yi system. However, as soon as the economics of the Hua-Yi system became unbalanced, tribute nations increasingly began to question the system, to become more self-reliant, and even to resist participation in the system.

Two separate cases might be useful for understanding this logic. The first is the China-Japan tribute relationship. Around the fourteenth to the sixteenth

8 Takeshi Hamashita 濱下武志, Choko System to Kindai Asia 朝貢システムと近代アジア

[Tribute System and Modern Asian] (Tokyo: Iwanami Shoten, 1997), 49-50.

9 Takeshi Hamashita, Choko System to Kindai Asia, 27-28. 
century, Japanese pirates operated in Chinese coastal waters, harassing China and conducting illegal trade. At the urging of the Ming emperor, the Ashikaga 足利義滿 shogun [1358-1408] agreed to suppress the pirate scourge and found formal trade relations with China. In 1402, a Japanese envoy returned home with the title of "Japanese king" given to him by the Chinese court. As the American scholar of Japanese history John Whitney Hall [1916-1997] has noted, Japan profited immensely from trade with the Ming dynasty. International trade became an important pillar of Japan's economy during this time. Japan exported large amounts of commodities and manufactured products to China, while ships returned to Japan bearing loads of currency (as much as 50,000 guan - a string of 1,00o coppers-in 1454), raw silk, porcelain, paintings, medicine, and books.

Without a doubt, the Hua-Yi system depended largely on the strength of economic ties. Even powerful countries had to prioritize material gains over moral considerations. Around this time, the formal bestowing of titles and offers of tribute started to lose the already-limited binding force that they had and even came to be seen as a way of surrendering power. Against this backdrop, the region known as "smaller China" [xiao Zhonghua 小中華] (typically referring to Korea, Vietnam, and Japan) emerged.

The question of "smaller China" became an essential one for scholars seeking to understand international relations in East Asia. Early on, the term symbolized an acknowledgment of the value of Chinese culture and even an attempt to mimic or assimilate to the culture. The Joseon dynasty in Korea never seemed to deny this: "In the east, since the time of Jizi 箕子 (a Chinese sage said to have ruled Joseon Korea in the eleventh century вСЕ), the men are martyrs and the women are righteous, in the annals this is known as smaller China." 10

Similar descriptions were also found in Vietnam, the only Southeast Asian country that truly entered into the sphere of Chinese cultural influence. From the Han [202 BCE-22O] to the Tang [618-907] dynasties, Vietnam was a province of China. It was not until the fifth century that the Vietnamese finally had a brief period of self-rule. When the Song emperor Xiao Zong 宋孝宗 [r. 1127-1194] made Ly Anh Tong 李天祚 [r. 1138-1175] emperor of Vietnam, then known as Annam, it marked the first time that the Central Plains dynasties had officially recognized Annam as a nation; during the reign of the Song emperor Lizong 宋理宗 [r. 1224-1264], the Chen 陳 dynasty [1225-140o] still exercised sovereignty over the region. The clear acknowledgment by Annam

10 Seongjong sillok 成宗實錄 [Annals of King Seongjong], in Chosŏn wangjo sillok 朝鮮王 朝實錄 [Annals of the Joseon Dynasty] (Tokyo: Gakushuindaigaku toyobunka kenkyujo, 1958), 15.237 . 
that it formed part of smaller China coincided with the Mongol 蒙古 invasion of China. In 1300, Emperor Trần Anh Tông 陳英宗 [r. 1293-1314] said: "You sit back and watch the disgrace of the sovereign and never feel sorrow; you are not ashamed to experience the national humiliation, and as a Chinese general you serve the barbarian chiefs without anger."11 After the Ming-Qing transition, when the Hua-Yi system fell into disorder for a while, the Vietnamese believed that they had preserved the system and carried on intact the traditions of ancient China, just as the Chinese had.

In Japan, the Hua-Yi system found its way into the culture early on, with no small number of Japanese considering themselves Chinese, Han, or Sinophiles. In 740, an inscription of Emperor Shomu 聖武天皇 [r. 724-749] mentioned the "northern barbarian Emisi [an ethnic group in Japan] are wild and difficult to tame. Since ancient times, the Chinese have imitated the sages and obeyed the emperors, while the imperial court has rebelled against the rules and betrayed the ancestors." 12

When the Hua-Yi system was forming in China's Central Plains, cultural indicators often surpassed racial differences as a categorization tool. Thus Zhu Yunying 朱雲影 [1904-1995] said: "It can be said that the difference between the Chinese and the barbarians is also the difference between civilization and savagery."13 Cultural markers, such as the Chinese language and Confucian rituals, were essential. At that time, Edo 江戶 period [1603-1867] intellectuals increased their understanding of the Hua-Yi system to the point that their identification with Chinese culture almost seemed to overshadow their national identity. Many of them believed that Chinese culture was universal and that its best elements could also be found in Japan. On this basis, to be Chinese meant to be steeped in the Chinese language and the Confucian tradition. Those who were not part of this world came to be seen as "barbarians" [manyi 蠻夷]. ${ }^{14}$ Through exchange between the Chinese and the non-Chinese peoples since ancient times, facilitated by the Hua-Yi system, Chinese values achieved broad recognition.

11 “Chenji 陳紀,” in Đại Việt sủ ký 大越史記 [The Historical Records of Dai Viet], vol. 6, quoted in Zhu Yunying 朱雲影, Zhongguo wenhua dui Ri-Yue-Han de yingxiang 中國 文化對日韓越的影響 [The Influence of Chinese Culture on Japan, Korea and Vietnam] (Guilin: Guangxi shifan daxue chubanshe, 2007), 210-11.

12 “Lie zhuan 列傳," in Dai Nihon shi 大日本史 [The Great History of Japan], ce 14, vol. 117, Tokyo, Honjo-ku Shinkoume-cho ichibanchi Koushaku Tokugawa, 1900.

13 Zhu Yunying, Zhongguo wenhua dui Ri-Yue-Han de yingxiang, 203.

14 Tsukamoto Manabu 塚本學, Kinse saiko: Chihou no shitenkara 近世再考: 地方の視點 から [Early Modern Reflections: A Local Perspective] (Tokyo: Nihon Editor School shupan, 1986), 86 . 
The significance of the Hua-Yi system seemed to be a sense of cultural pride. In both a geographic and a moral sense, "Chinese" [Zhonghua 中華] had the connotation of "central," and so the Hua-Yi system referred to the borderlands surrounding and protecting a cultural and economic core. Therefore, the peoples who strove to emulate Chinese values but were viewed as inferior to the core "Chinese" culture had to surpass the more advanced culture in order to raise their own status. To various extents, these societies did so by copying the Hua-Yi system or by creating their own Hua-Yi systems centered on their own culture.

In the time of Japan's Ritsuryo system (the legal and political structure used to govern the country), distant political and cultural centers were often called "barbarian." The Chinese concept of differentiating the Chinese from barbarians implied a high level of cultural dispersion and incentive mechanisms for this dispersion that were closely connected to the geographical form of mainland China. Similarly, in Japan, the territory in and around the capital [jinei 畿內], Kyoto, was considered "Chinese" [hua 華], and the remote areas outside the capital [jiwai 畿外] were "barbarian."

Around the eighth century, this differentiation between the urban area of Kyoto and the areas outside Kyoto evolved into a system that approximated China's Hua-Yi system. During the Edo period in the seventeenth century, history books rarely contained the term "barbarian." Japanese scholars believe this is because after the cultural dispersion of the Middle Ages, Japan went through a period of integration and national consolidation. What is worth noting is that, although Edo Japan could no longer be considered an economic or political vassal state of China, until the mid-eighteenth century Japanese intellectuals still viewed Chinese culture as superior. This is why the transition from the Hua-Yi system to nationalism largely played out during the emergence of other civilizations under the umbrella of Chinese culture. ${ }^{15}$

Since the period of Sui emperor Yang 隋煬帝 [r. 604-617], when the Japanese emperor wrote to China that, "The Son of Heaven at the sunrise wishes good health for the Son of Heaven at the sunset"16 and made other provocative remarks, the desire to challenge China's status-which developed out of the idea of Japan as a part of "smaller China" - continued unabated. For example, at the end of a period of peace that coincided with the decline of the Tang dynasty, Japan referred to the Tang empire as "the various vassal states." In 1610, the Edo period samurai Honda Masazumi 本多正純 [1566-1637]

15 Tsukamoto Manabu, Kinse saiko: Chihou no shitenkara, 86-94.

16 Wei Zheng 魏征, Linghu De 令狐德 et al., "Dongyi liezhuan 東夷列傳 [Biographies of the Eastern Barbarians]," in Sui shu 隋書 [History of the Sui Dynasty] (Beijing: Zhonghua shuju, 1973), 81.1827. 
presented the Ming dynasty with letters noting that "tribute from the people of Korea, the Ryukyu Islands, Annam, Jiaozhi [in northern Vietnam], Siam, Luzon, the Western world, Cambodia, and other barbarian chiefs, without exception, all have presented letters and sent guests." ${ }^{17}$ In this way, the Japanese demonstrated their strength to the Ming and showed that they possessed their own Hua-Yi system.

During Vietnam's Nguyen 阮 dynasty [1802-1945], as China grew stronger, the small Hua-Yi systems surrounding it began to increase in scale. According to the records, the period just before the start of the Opium War [1840-1842] was the golden age of the Nguyen dynasty. During this period, Vietnam consolidated its territory and annexed Cambodia 柬埔寨, Laos 老擑, and a number of other nations on its borders. Korea considered Bukbang Uiju 北方義州, Hoeryong 會寧, and others to be "barbarian" regions under its own version of the Hua-Yi system..$^{18}$ Because of this, in a certain sense, Southeast Asia had a two-layered Hua-Yi system: the system centered on China and various copies of the Chinese system with China's vassal states at their core.

\section{3}

The Ming-Qing transition represented a major discontinuity in the Hua-Yi system, which in China had traditionally been based on the distinction between civilized and "savage" societies. Although Vietnam advocated for strict separation between the Chinese and the non-Chinese barbarians, the Ly 黎 regime [1428-1789] at the time also secretly supported the bloodline of King Gui 桂 [1623-1662] of Burma 緬甸 (present-day Myanmar), who represented the surviving forces of the Southern Ming dynasty [1644-1683]. However, when the Ly clan realized that King Gui was in a hopeless situation and that the scattered survivors of the Southern Ming dynasty could easily be wiped out by the Qing, they quickly decided to take the initiative to dispatch an envoy to the Qing to establish tributary relations with them in the name of the king of Annam. This took place in 166o, a year before King Gui was captured. What is interesting is that the Mo 莫 clan [1527-1683], rivals of the Ly, followed a similar strategy. In 1804, during the reign of the Nguyen dynasty, Gia Long 阮福映 [1762-1820], born Nguyễn Phúc Ánh, was named the king of Vietnam by the Qing dynasty and established a tributary relationship with the Qing. Although the Nguyen shied away from the term "tribute," preferring to refer to "diplomatic relations"

\footnotetext{
17 Dai Nihon shiryō 大日本史料 [Great Japan Archives], chapter 7 of 12 (Tokyo: Tokyo Daigaku, 1905), 847.

18 Tong mun gwan ji 通文館志, Huigwi doseo hyeobhoe 韓國珍書刊行會, 1907.
} 
[bangjiao 邦交], this suggested that the tributary relationship between the Qing and the Nguyen had gradually become a form of ceremonial relations. ${ }^{19}$ The kinship ties between China and Vietnam are still faintly discernible in the shared history and culture of both countries.

Compared to Vietnam, Korea had a more extreme reaction to the Ming-Qing transition. In 1636, the Joseon dynasty official Zhao Gang 趙綱 said:

All the world has heard that our country's essence is righteousness, this is called smaller China, and all the saints share the same sacredness, and are devoted to one thing, and are thorough and diligent. Now we serve the northern barbarians, and we must seek a moment's peace however one can. What does this mean for our ancestors, for the world, and for future generations! ${ }^{20}$

However, when an envoy visited the imperial palace in Chengde 承德, he realized that although the Qing had distinct clothing, hairstyles, and administrative structures, they had no obvious moral differences from the Ming. So the envoy told the Koreans: "Learn the heritage of the Chinese people and change our customs first, then say that there is nothing about China to appreciate."21 Not long after the Joseon established tributary relations with the Chinese, they began to follow the Chinese calendar.

But during the upheaval on the Chinese mainland, Japan's response was the most dramatic. The desire to lessen Chinese influence and replace the Sino-centric geopolitical system with a Japanese-style Hua-Yi system, previously only alluded to, finally emerged into the open. The Edo shogunate had been watching the changes in Ming and Qing China closely, especially the Hua-Yi system and the changes brought about by the Ming-Qing transition, which it deliberately played up. Because of Japan's geographic location, the Japanese had historically been seen as the "eastern barbarians." Historian Arano Yasunori 荒野泰典 has said that the self-centeredness and cultural superiority associated with the Hua-Yi system inspired Japan to try to recreate a similar system with Japan as the core. What is important is that the Japanese style Hua-Yi system was built "just as the Qing was raising its head, and during the decline of the Ming, and just as the Dutch were asserting hegemony

19 Kham định Đại Nam hội điển sự lệ 欽定大南會典事例 [Imperial Authorized Records of the Nhà Nguyễn], Tokyo, Toyo Bunko, vol. 128 .

20 Injo sillok 仁祖實錄 [Annals of the King Injo], in Chosŏn wangjo sillok (Tokyo: Gakushuindaigaku toyobunka kenkyujo, 1962), 35.162-63.

21 Bak Ji-won, Rehe riji, 6o-61. 
in the European sphere of influence." ${ }^{22}$ It was "rooted in the changes the entire region was experiencing during the Ming-Qing transition."23

There was asymmetry between the official messaging of the late Ming regime and the reality on the ground, which exacerbated Japan's tendency to overstate the impact of the Ming-Qing transition. According to official statistics, during the Qing invasion, the surviving forces of the Ming dynasty asked Japan for military help or reinforcements seventeen times. This directly affected Edo Japan's perception of the Manchu 滿洲 people as well as of the Chinese. Ura Renichi 浦廉一 has noted that during the upheaval of the Ming-Qing transition, Japan began to "view Manchuria as barbarian and to call them Tartars 鞋靼 and became increasingly scornful of them. At the same time, they were sympathetic to the Korean peninsula, which was the continual target of Manchurian invasions, and to the Ming dynasty."24 These sentiments increasingly suffused both the government and the [Japanese] public. This propaganda had a negative effect for Qing scholars, who came to be considered barbarians. For the Japanese who sought to use this as a pretext to form their own Hua-Yi system and to "take care of" the Qing problem, however, things appeared to have resolved themselves.

This tacit understanding extended to the world of entertainment. In the dramatic play Guoxing ye he zhan 國性爺合戰 [The Battle of Koxinga], which told the heroic tale about Zheng Chenggong 鄭成功 ([Koxinga] 1624-1662) repelling the Qing, had a major impact on Japanese society. It is reported that on November 1, 1715, when this play was presented in Osaka 大阪 for the first time, over 80 percent of Osaka's 300,ooo residents went to see it. The play ran for seventeen months over three years, a feat considered unprecedented and unrepeatable in the history of Japanese theater. ${ }^{25}$ Because the play contained references to the Manchus as "Tartars" who were "like domestic animals" [chulei tongran 畜類同然], for example, the work was highly effective in spreading the ideas of the Hua-Yi system. ${ }^{26}$

22 Arano Yasunori 荒野泰典, Kinsei Nihon to higashi Asia 近世日本と東アジア [Early Modern Japan and East Asia] (Tokyo: Tokyo daigaku shuppan-kai, 1998), 31.

23 Arano Yasunori, Kinsei Nihon to higashi Asia, 34.

24 Ura Renichi 浦廉一, annot., “Kaihentai-kaidai tousenhusetusho no kenkyu 華夷變態解 題: 唐船風說書の研究 [Illustration of Transformation from Hua to Yi: Research on the Rumors Brought to Japan by Tang Ships]," in Ka-i hentai 華夷變態 [Transformation from Hua to Yi], ed. Hayashi Harukatsu 林春勝 and Hayashi Nobuatsu 林信篤 (Tokyo: Toyo bunko, 1958-1959), 22-23.

25 Ishihara Michihiro 石原道博, Koxinga 國姓爺 [Lord of the Imperial Surname] (Tokyo: Yoshikawa kobunkan, 1986).

26 Tsukamoto Manabu, Kinse saiko: Chihou no shitenkara, 102. 
Japan's response was so strong largely because it had long been subject to the derogatory name $y i$ di 夷狄 [barbarian] itself. If the status of the Qing as $y i$ $d i$ implied fluidity between Chinese and barbarian, then it was impossible for people or nations who dismissed the Qing as yi to be $y i$ themselves - this was the logic of the Japanese. But they would never have thought that their status would change entirely in the course of one night, as it did when the former Ming dynasty forces sought military aid from Japan. Although Japan ultimately did not send troops, the incident made the nation conscious that not only had it completely shaken off its status as yi di but it was also on the verge of becoming a power capable of repelling the barbarians in its own right- the eastern representative of China. ${ }^{27}$

Japan's policies toward China during this period brought about a subtle reversal in the relative status of the two nations. Following trade frictions with the Qing dynasty, in early March 1715 the Tokugawa shogunate issued its own trading regulations. They stipulated that Chinese ship owners had to present documents to the shogunate, either a ship license or a certificate of trading relations with Nagasaki 長崎, in order to berth there. The regulation severely restricted trade volume between Japan and China and made clear the disdain the Tokugawa had for the Qing or "Qing barbarians" [Qingyi 清夷]. In May 1717, Emperor Kangxi 康熙 [r. 1661-1722] accepted the terms of the new regulations, noting by way of explanation that China required copper from Japan to mint coins. This ultimately meant that the ritual status of Japan and China had been reversed and that Japan had succeeded in holding firm and projecting its national power. ${ }^{28}$

Japan's willingness to step boldly onto the world stage was tied to the changing geopolitical makeup of the region. During the Middle Ages, the Japanese believed that there were only three countries in the world: Japan, China, and India. Although Japan was influenced by these other countries, the designation of the Japanese emperor as the emperor of heaven at this time ushered in a change of thought that strove to make subjects believe Japan was its own self-contained world, unmatched by any other nation. In the modern period, following greater knowledge of the outside world, Japan's three-country

27 Ishihara Michihiro, Minmatsu shinsho Nihon kitsushi no kenkyu 明末清初日本乞師 の研究 [Research on Asking for Japanese Military Help in the Late Ming and Early Qing Dynasties] (Tokyo: Huzanbo, 1945), 124.

28 Miyazaki Michio 宮崎道生, Arai Hakuseki no kenkyu 新井白石の研究 [Research on Arai Hakuseki], expanded edition (Tokyo: Yoshikawa kobunkan, 1984), 192-93; Han Dongyu 韓東育, “Guanyu dongya jinshi hua-yi guan de fei duichen qibian 關於東亞 近世華夷觀的非對稱畸變 [The Asymmetric Distortion of Hua-Yi Concept in Modern East Asian]," Shixue lilun yanjiu 史學理論研究, no. 3 (2007). 
worldview dating back to the Middle Ages was replaced by a new three-country system centered on Japan, Tang China, and the West. The idea that "China" as it was known disappeared with the "barbarian conquest" and the chaos of the Ming-Qing transition provided an opening for the creation of this new system. It also provided an opportunity for the Tokugawa shogunate to directly represent the Eastern world in its dealings with the West.

The Opium War likewise represented an opportunity for Japan, and the decline in status of the former Tang dynasty suddenly became a foregone conclusion. In the Meiji Restoration 明治維新 [began 1868] and the Sino-Japanese War [1894-1895], Japan essentially realized its goal of undermining the China-centered Hua-Yi system and the tribute system. ${ }^{29}$

Arai Hakuseki's 新井白石 [1657-1725] changes in trade policy and his new geopolitical order showed, in a more fundamental sense, that Japan could no longer benefit from the tribute system. Japan's sluggish economy led many to resort to untoward means to get ahead, and some even saw the Ming-Qing transition as a chance for personal gain. Although many Japanese supported sending military forces to suppress the Qing on ideological grounds, no aid was sent in the end. The Tokugawa shogunate did see an unexpected financial benefit, however, as it sold arms to the Ming forces. The Japanese also occasionally tried to use the various Chinese forces against one another. The Ryukyu 琉球 kingdom had been a neutral state since the fifteenth century because of its geographic location between Japan and China. After the Ming-Qing transition, it accepted a title offered by the Qing and entered into tributary relations with China. However, Japan's strategy of pitting the Chinese against one another for a time pushed Ryukyu closer to Japan and bought time for Japan to realize its ultimate goal of establishing a Japanese style Hua-Yi system.

The Tokugawa shogunate's early Japanese-style Hua-Yi system was largely conceptual, rather than a tangible social order. Matsumae 松前, Nagasaki, Tsushima 對馬, and Satsuma 薩摩 became the four nodes of the system and formed networks separately with the Ainu 阿伊努, China, the Netherlands, Korea, and Ryukyu, forming a system of center-periphery relations and fulfilling Japan's aspirations of many years. Under this system, the Chinese were unambiguously classified as barbarians. ${ }^{30}$

\footnotetext{
29 Arano Yasunori, Kinsei Nihon to higashi Asia, 53-56.

$30 \quad$ Han Dongyu, "Guanyu dongya jinshi hua-yi guan de fei duichen qibian."
} 
Japan's post-Edo-era Hua-Yi system, compared to that of its neighbors Korea and Vietnam, was characterized by a transition away from culture-based classifications and a greater emphasis on nationalism. It became clear that Japan hoped to fulfill China's earlier role in East Asia. Of course, Japan, Korea, and Vietnam banded together with China to repel invasions by foreign powers under the banner of honoring the emperor and repelling the barbarians, indicating that a strict interpretation of the Hua-Yi system still had some utility in East Asia.

Comparing the protracted resistance to foreign powers by China, Korea, Vietnam, and Japan, it was Japan's half-hearted efforts to repel the barbarians and its practice of playing other nations against one another that irreversibly changed the Hua-Yi system. Japan effectively cooperated with the Western powers' efforts to upend the East Asian system and sow discord among the nations in the region. This damaged the system on which Japan relied for its own growth.

Western modernity no doubt brought the concepts of the nation-state, industrial society, and modern prosperity to the region. But this demonstrates that even before the introduction of the concept of the Western nation-state, the various East Asian nations already possessed a relatively fixed ethnic and national consciousness. From a historical perspective, Japanese support for the independence of the nations in the region altered the interconnected kinship relations that had previously characterized East Asia.

However, all the challenges of the Hua-Yi system were essentially rooted in the structure of the system itself. The Hua-Yi concept brought civilization to East Asia but also sowed the seeds of ethnocentrism. As previously discussed, the Hua-Yi system referred to a system of rituals and hierarchy, whereas the tribute system was a series of economic and political networks built on the foundation of the Hua-Yi system. The tribute system was characterized by practices including conferring titles and offering tribute based on assumptions of relative superiority and inferiority, a distinction that dated back to ancient times. However, almost from their beginning the Hua-Yi system and the tribute system were tainted by ethnocentrism, an ideology that elevated one's own ethnic group or clan over others. In many cases, this applied to the clan bearing the family name of a given dynasty — for example, the Si during the Xia dynasty [2100-16оо вСE], the Zi during the Shang dynasty [1600-1400 BCE], and the Ji during the Zhou dynasty [1046-256 BCE]. Ethnocentrism played an important role in advancing Chinese civilization and spreading its culture, because the clan system facilitated territorial expansion through networks of alliances. At 
the same time, it gave members of other clans who were incorporated into this system a sense of cultural and moral inferiority and provided a template that allowed ethnocentrism to be perpetuated.

Within the Hua-Yi system, legitimacy was often won by force, which made animosity toward other ethnicities nearly inevitable. For this reason, the Hua-Yi system helped to promote a common value system and the spread of civilization but, at the same time, also spurred the rise of foreign powers. Within the framework developed by the Hua-Yi system, non-Chinese dynasties were virtually compelled to attempt to invade and overthrow the Central Plains dynasties if they possessed sufficient resources. Only in this way could they finally be seen as legitimate. Zhu Yunying's view is worth considering: he believes the Hua-Yi system is the source of nationalism in the East and serves as a motivation for less developed countries to catch up to the more developed nations, inspiring in them a determination to succeed. But, if taken too far, the Hua-Yi system may be used as a weapon to exclude certain groups. ${ }^{31}$

\section{Translated by Colleen Howe}

\section{Works Cited}

Arano Yasunori 荒野泰典. Kinsei Nihon to higashi Asia 近世日本と東アジア [Early Modern Japan and East Asia]. Tokyo: Tokyo daigaku shuppan-kai, 1998.

Bak Ji-won 樸趾源. Rehe riji 熱河日記 [The Diary in Rehe]. Shanghai: Shanghai shudian chubanshe, 1997.

Dai Nihon shi 大日本史 [The Great History of Japan]. Tokyo: Honjo-ku shinkoume-cho ichiban chi koushaku Tokugawa, 1944.

Dai Nihon shiryō 大日本史料 [Great Japan Archives]. Tokyo: Tokyo University, 1905.

Fairbank, John King 費正清. Zhongguo: Chuantong yu bianqian 中國:傳統與變遷 [China: Tradition and Transformation]. Translated by Zhang Pei 張沛. Beijing: Shijie zhishi chubanshe, 2002.

Han Dongyu 韓東育. “Guanyu dongya jinshi hua-yi guan de fei duichen jibian 關於 東亞近世華夷觀的非對稱畸變 [The Asymmetric Distortion of Hua-Yi Concept in Modern East Asian]." Shixue lilun yanjiu 史學理論研究, no. 3 (2007): 11-15.

Han Fei 韓非. Han Feizi jijie 韓非子集解 [The Collected Commentaries on Han Feizi]. Annotated by Wang Xianshen 王先慎. In Zhuzi jicheng 諸子集成 [Collected Interpretations of Zhuzi], vol. 5. Shanghai: Shanghai shudian, 1986.

31 Zhu Yunying, Zhongguo wenhua dui Ri-Yue-Han de yingxiang. 
Hayashi Harukatsu 林春勝 and Hayashi Nobuatsu 林信篤, ed. Ka-i hentai 華夷變態 [Transformation from Hua to Yi]. Annotated by Ura Renichi 浦廉一. Tokyo: Toyo bunko, 1958-1959.

Injo sillok 仁祖實錄 [Annals of the King Injo]. In Chosŏn wangjo sillok 朝鮮王朝實錄 [Annals of the Joseon Dynasty], vol. 32. Tokyo: Gakushuindaigaku toyobunka kenkyujo, 1958.

Ishihara Michihiro 石原道博. Koxinga 國姓爺 [Lord of the Imperial Surname]. Tokyo: Yoshikawa kobunkan, 1986.

Ishihara Michihiro 石原道博. Minmatsu shinsho Nihon kitsushi no kenkyu 明末清初日 本乞師の研究 [Research on Asking for Japanese Military Help in the Late Ming and Early Qing Dynasties]. Tokyo: Huzanbo, 1945.

Kham định Đại Nam hội điển sự lệ 欽定大南會典事例 [Imperial Authorized Records of the Nhà Nguyễn]. Tokyo: Toyo Bunko.

Li Wenfeng 李文鳳. Yue qiaoshu 越嶠書. Taiwan lishi yuyan yanjiusuo tushu guan, manuscript edition.

Miyazaki Michio 宮崎道生. Arai Hakuseki no kenkyu 新井白石の研究 [Research on Arai Hakuseki], expanded edition. Tokyo: Yoshikawa kobunkan, 1984.

Seongjong sillok 成宗實錄 [Annals of the King Seongjong]. In Chosŏn wangjo sillok 朝鮮王朝實錄 [Annals of the Joseon Dynasty], vol. 20. Tokyo: Gakushuindaigaku toyobunka kenkyujo, $195^{8}$.

Takeshi Hamashita 濱下武志. Choko system to kindai Asia 朝貢システムと近代アジア [Tribute System and Modern Asian]. Tokyo: Iwanami shoten, 1997.

Tong mun gwan ji 通文館志. Huigwi doseo hyeobhoe 韓國珍書刊行會, 1907.

Tsukamoto Manabu 塚本學. Kinse saiko: Chihou no shitenkara 近世再考: 地方の視點 から [Early Modern Reflections: A Local Perspective]. Tokyo: Nihon Editor School shupan, 1986.

Wei Zheng 魏征, Linghu De 令狐德 et al. Sui shu 隋書 [History of the Sui Dynasty]. Beijing: Zhonghua shuju, 1973 .

Xie Zhaozhe 謝肇淛. Wu za zu 五雜組. Annotated by Fu Cheng 傅成. Shanghai: Shanghai guji chubanshe, 2012.

Zhang Tingyu 張廷玉 et al. Mingshi 明史 [History of the Ming Dynasty]. Beijing: Zhonghua shuju, 2000.

Zhu Yunying 朱雲影. Zhongguo wenhua dui Ri-Yue-Han de yingxiang 中國文化對日韓 越的影響 [The Influence of Chinese Culture on Japan, Korea, and Vietnam]. Guilin: Guangxi shifan daxue chubanshe, 2007. 